\title{
Sequential Learning in Unconventional Packaging?
}

\author{
By Terry Cottrell and Rebecca P. Butler
}

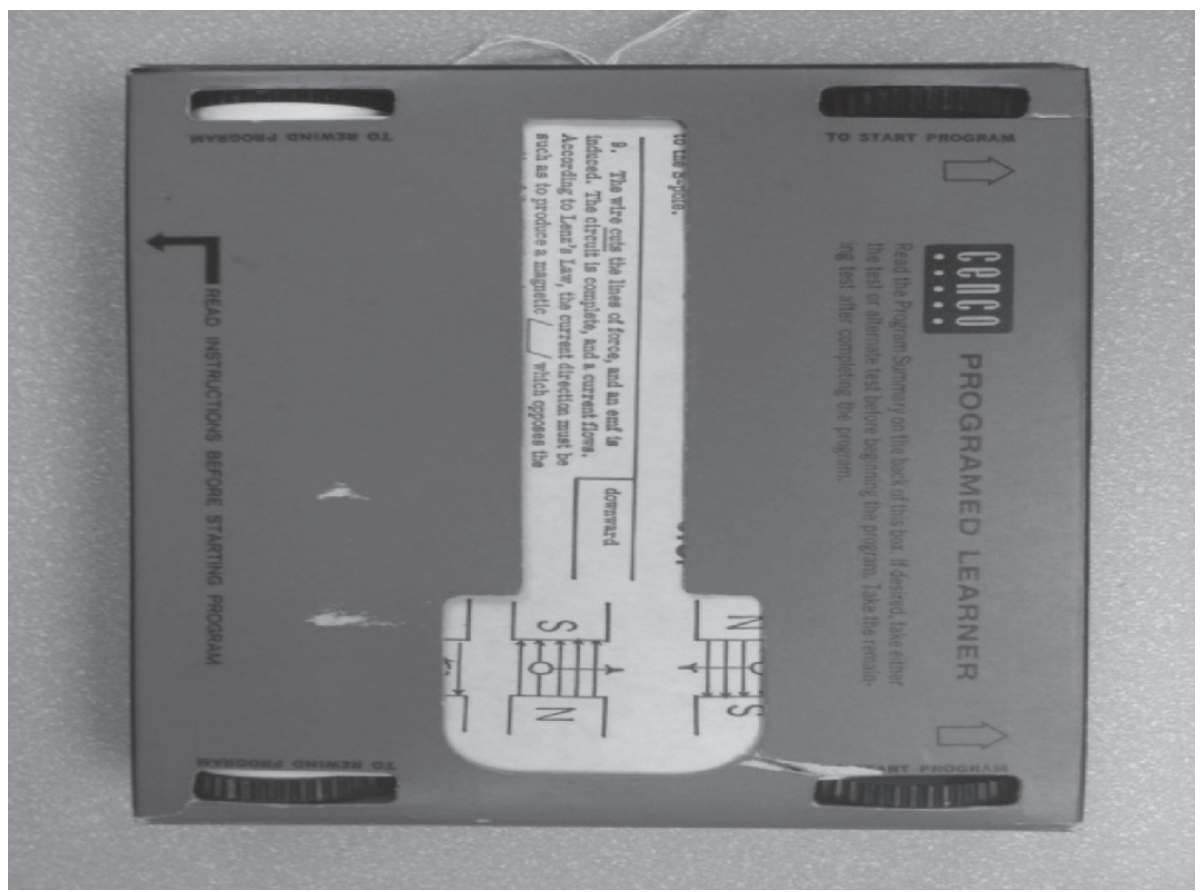

The Cenco Programmed Learner no. 58302-2 "Alternating Current" Lee and Lida Cochran AECT archives

Blackwell Museum of Education, Northern Illinois University 1999

$\mathbf{P}$

rogrammed learning came to the education field in the 1930s through the work of B.F. Skinner and his investigations of operant conditioning-the theory that response from a learner comes after a stimulant is introduced to a given situation, and not before (Saettler, 2004).

Used in the U.S. in the early 1960s, the Cenco Programmed Learner is a cardboard box containing two cardboard paper scrolls with approximately seventy-five feet of paper between the two rolls on opposing ends. On the end of each scroll roller is a plastic, notched roller wheel allowing users to advance (by rolling downward toward their feet) or retract the viewable written content.
The box is approximately eight inches in width and two inches thick.

The Cenco's lesson modules are written sequentially, and the text of each module is presented to users inside a small six inch wide by two inch high cut-out window frame in the front of the unit. A frame number is located in the upper left hand corner of each frame cut-out. This number serves as a guide post as learners read through the module. The Cenco is a self-paced learning device in the sense that the lesson cannot begin unless users scroll down on the scroll wheels. If learners choose to re-read a section of the module, they can simply scroll up to the last section, and use the frame numbers as a guide to where they last left off.
Because users must construct the answers themselves, the Cenco Programmed Learner reinforces active learning. Individuals are required to formulate (physically) part of the lesson's content-on their own-which draws them deeper into the lesson, making them co-creators of content.

\section{Reference}

Saettler, Paul. (2004). The evolution of American educational technology. Greenwich: Information Age Publishing.

\section{Bibliography}

Back Matter. (1966, December) Journal of Reading, 10(3).

Fry, Edward. (1964, April). Programmed instruction in reading. The Reading Teacher, 17(6), 453-459.

Friedman, D. P., \& Felleisen, M. (1996). The Little schemer (4th ed.). Cambridge: The MIT Press.

Lee and Lida Cochran AECT Archives. (1999). The Cenco Programmed Learner No. 583022 "Alternating Current". DeKalb, Illinois: Blackwell Museum of Education, Northern Illinois University. November 12, 2009. http://www.cedu.niu.edu/blackwell/multimedia/high/library.html

New York Institute of Technology. (2006). The 1950s. Retrieved from http://www.nyit.edu/ magazine/2006/winter/features/the50s.php

Paselk, Richard. (1998). Central scientific company: A brief history. Retrieved from http://humboldt.edu/ scimus/Manufac/ Cenco/Cenco.htm

President \& Fellows of Harvard College. (2008). Cenco Instruments Corp. - Lehman Brothers Collection. Retrieved from http:// www.library.hbs.edu/hc/lehman/chrono. html?company=cenco_instruments_corp

Schure, Alexander. (1964). Alternating Current: Cenco No. 58302-2. New York: Educational Aids Publishing Corp.

University of Houston. (n.d.). B.F. Skinner. Retrieved from http://www.coe.uh.edu/ courses/cuin6373/idhistory/skinner.html 